\title{
K VYUŽITÍ SÉMANTICKÉHO DIFERENCIÁLU PŘI AUTOEVALUACI ŠKOLY
}

\author{
JANA VAŠŤATKOVÁ, MARTIN CHVÁL
}

Anotace: České školy postrádají spolehlivé nástroje využitelné v rámci práce se zpětnou vazbou. Metoda sémantického diferenciálu v konkrétní úpravě ATER nabízí měrení postojü žáků k vybraným pojmům pedagogické reality. Na př́kladě třech škol jsou predstaveny výsledky jeho využití ve vzájemném porovnání, což je v anonymizované podobě cenným zdrojem informací pro autoevaluaci škol. Předložený text podrobněji analyzuje metodu sémantického diferenciálu v porovnání Osgoodovy původní práce a úpravě ATERu. Skrze prezentované príklady dospivá k obecnějším možnostem jeho využitív autoevaluaci školy.

Klíčová slova: autoevaluace školy, sémantický diferenciál, faktorová analýza, škála, Osgood, ATER

Abstract: Czech schools lack reliable tools usable for their work with feedback. The method of semantic differential in the form of ATER offers measurement of pupils ' attitudes towards particular concepts of educational reality. Using the example from three schools, results of its use are introduced. Their comparison in the form of anonymous feedback is a valuable source of information for school self-evaluation. The presented text analyses the method of semantic differential while comparing Osgood original work with ATER adaptation in a detailed way. Through presented examples it concludes more general possibilities of use during school self-evaluation.

Key words: school self-evaluation, semantic differential, factor analysis, Osgood, ATER

\section{1 ÚVOD}

České školy jsou v situaci, kdy jsou povinovány získávat různými způsoby zpětnou vazbu o své práci: realizovat autoevaluaci. Na autoevaluaci lze nahlížet z mnoha perspektiv: jedná se o jistou formu odpovědnosti škol navenek; o prostředek umožňující participaci různých osob na životě školy; o cyklický proces k nastartování a řízení změn ve škole ( $v$ ideálním příkladě se jedná o změny podporující žádoucí rozvoj školy); o spirálovitý proces řízení kvality apod. $V$ české školské realitě se $k$ tomuto výčtu řadí $i$ to, že se jedná o relativně novou "povinnost" škol (srov. Zákon... 2004; RVP ZV 2007 aj.). Autoevaluace bývá přirovnávána k zrcadlu, které nastaví škola sama sobě, jinými slovy řečeno, jedním z nejdůležitějších momentů je co nejobjektivnější poznání reality (se kterým se následně pracuje). $\mathrm{K}$ tomuto účelu je možné využít nejrůznější metody, nástroje či techniky; jejich seznam je uveden např. ve Vaštatková (2007). Některé jsou v českém prostředí užívány hojně (např. 
rozhovory, dotazníky), jiné zatím sporadicky či vůbec. Mezi nástroje, které na své častější využití čekají, patří i sémantický diferenciál. Záměrem textu příspěvku je přibližit možnosti využití nástroje ATER vytvořeného na bázi sémantického diferenciálu při autoevaluaci školy. Za tímto účelem bude nejprve sémantický diferenciál charakterizován, analyzována metodologie jeho vzniku a úprava v dotazníku ATER. Uvedené bude použito pro analýzu dat získaných z šetření ve třech základních školách.

\section{SÉMANTICKÝ DIFERENCIÁL}

Sémantický diferenciál je považován za metodu k měření postojů; bývá řazen mezi tzv. psychosémantické metody (srov. Miovský 2006, s. 193). Vyznačuje se spojením psycholingvistiky, psychologie vnímání a psychologie individuálního vědomí (Maršálová; Mikšík a kol. 1990). Postoji jsou rozuměny "trvalé soustavy pozitivních nebo negativních hodnocení, emocionálního cítění a tendencí jednat pro nebo proti vzhledem ke společenským objektům" (Bedrnová; Nový 1998, s. 58); v každém postoji Ize rozlišit stránku kognitivní (hodnotící), emocionální (citovou) a konativní (tendenci jednat vůči objektu) (tamtéž). $V$ tomto smyslu jde sémantický diferenciál hlouběji než běžné dotazníkové metody tím, že respondentům není zřejmá úroveň zpracování dat, a nemohou tedy vědomě korigovat výsledky, které svými odpověd'mi poskytují. Na druhou stranu sémantický diferenciál z principu nemůže postihnout konativní aspekt postojů. Proto jsou někteří autoři zdrženlivější z hlediska toho, co vlastně sémantický diferenciál měří, a mluví např. o měření významů (Nakonečný 1997, s. 100). ${ }^{1}$

Sémantický diferenciál byl původně vyvinut C. Osgoodem (spolutvưrci byli G. J. Suci a P. H. Tannenbaum) a je založen na umistování pojmu, který reprezentuje určitý jev na škálách, do mnohorozměrného sémantického prostoru. Vyhledáním faktorů v těchto škálách (jejichž póly tvoří dvojice protikladných adjektiv) Ize umístit sledované pojmy do vytvořených souřadnic. Sémantický diferenciál je výsledkem syntéz metody škálovací a asociační, nebot' ve své klasické podobě umožňuje měřit konotativní významy pojmů2, tj. jejich individuální, psychologické významy u lidí. Umožňuje výzkumníkovi průnik do vnitřního světa zkoumané osoby a získání vysoce individualizované informace, se kterou je možno dále statisticky pracovat a nezávisle ji ověřovat. Spojuje tak v sobě vlastnosti kvantitativních a kvalitativních výzkumných postupů, nebot' je možno zkoumat jak jedince, tak skupiny respondentů a zjištovat shodné vnímání vybraných pojmů i vývoj tohoto vnímání v čase. Předností sémantického diferenciálu je podle Pelikána (2004, s. 149) „hlubší proniknutí do individuálního chápání významu jednotlivých pojmü"a teoreticky velká variabilita jejího využití: může přinést užitečné výsledky $v$ různých společenských vědách či disciplínách, v pedagogice např. v obecné pedagogice, v oborových didaktických,

1 Osgood (1957) anglicky označil "meaning".

2 Pojem je určen definicí, která udává podstatné vlastnosti určitého pojmu, jež ho odlišují od jiných. 
v muzejní pedagogice, ve školském managementu. ${ }^{3}$

Sémantický diferenciál však není metodou univerzální a bezproblémovou, a i patrně proto není jeho využití v českém školním prostředí př́liš běžné. Zdánlivý opak je způsoben např. záměnou běžných škál za sémantické diferenciály, podceňováním poměrně široké škály rizikových momentů spjatých s jejich využíváním (podrobněji viz např. Vala; Vaštatková 2009). Postup při tvorbě a užití sémantického diferenciálu je uveden u řady autorů (např. Pelikán 2004; Chráska 2007). Následující část textu se zaměří na jednu ze základních problematik konstrukce konkrétního sémantického diferenciálu. Jedná se o reprezentativnost a relevanci adjektiv. Pozornost bude též věnována možnostem prezentaci získaných dat.

\subsection{REPREZENTATIVNOST A RELEVANCE ADJEKTIV PŘI TVORBĚ SÉMANTICKÉHO DIFERENCIÁLU}

Při tvorbě sémantického diferenciálu stojí výzkumník před různými volbami počínaje výběrem pojmů, škál, přes způsoby zpracování a interpretace dat až po možnosti jejich prezentace. Ke zvolenému pojmu má být vždy vybrána dvojice adjektiv reprezentující jednu dimenzi relevantní zvoleným pojmưm. Každá dimenze má být zastoupena reprezentativním vzorkem těchto dvojic (srov. např. Ferjenčík 2000). Celkový počet dimenzí odpovídající počtu bipolárních adjektiv je možno redukovat pomocí faktorové analýzy, která vychází z předpokladu existence latentních proměnných, jejichž počet je nižší než počet proměnných pozorovaných (Blahuš 1985, McDonald 1991). Existují dva základní druhy faktorové analýzy: explorační (využívá se při seskupování, při sdružování či hledání skupin u dosud neznámých proměnných) a konfirmační (která je více striktní a ověruje známý soubor faktorů v hypotetickém modelu vztahů a klastrů) (srov. Cohen; Manion; Morisson 2007; Hendl 2004). Výsledky faktorové analýzy jsou ovlivněny několika rozhodnutími výzkumníka: 1) volbou druhu a metody faktorové analýzy, 2) volbou optimalizace pro hledání rotovaného řešení, 3) stanovením hranice pro počet faktorů určených $\mathrm{k}$ interpretaci, 4) interpretací faktorů a jednoznačným přiřazením dvojic adjektiv k dimenzím.

Zásadní rozhodnutí pro určení počtu výsledných faktorů se realizuje prostřednictvím statistického SW bud' prímo stanovením jejich počtu výzkumníkem nebo stanovením minima vlastních čísel faktorů (tzv. „eigenvalues“). Minimum vlastních čísel se běžně zadává na 1, což odpovídá tomu, že každý nalezený faktor má vysvětlit více variability rozptylu než v průměru jednotlivá dvojice adjektiv (nalezené faktory pak v součtu vysvětlí kolem $50 \%$ celkového rozptylu).

Do rozhodování výzkumníka se promítá ještě i možnost interpretace nalezených faktorů. Tomu napomáhá hledání rotovaného řešení faktorové analýzy. Geometricky se jedná o různé natáčení nových os faktorového prostoru tak, aby se faktorům odpovídajícím těmto osám dalo dobře rozumět, k čemuž napomáhají korelační koeficienty v matici faktorových zátěží (ta vyjadřuje právě korelace hledaných faktorů

3 Pasáž byla z inspirována z Vala; Vaštatková (2009). 
s původními škálami). Vysoké korelační koeficienty (blíže k 1 nebo -1) nabízejí pro daný faktor interpretaci přes korelovanou dvojici adjektiv. ${ }^{4}$ Obdobně se rozhodoval Osgood (in Osgood; Suci; Tannenbaum 1957) a následně se často užívá "jednodušší interpretace jeho závěrů, která se promítá do tradování o sémantickém diferenciálu v metodologických učebnicích. ${ }^{5}$ Následující podkapitola nastíní, jak, resp. na základě jakých údajů, vznikla tato tradovaná zjednodušení.

\subsubsection{OSGOODOVA ANALÝZA}

V padesátých letech minulého století realizoval Osgood výzkum se 100 respondenty, studenty psychologie. Vybral 50 dvojic adjektiv (viz Osgood; Suci; Tannenbaum 1957, v českém překladu např. Chráska 2007) a 20 následujících pojmů: LADY, BOULDER, SIN, FATER, LAKE, SYMPHONY, RUSSIAN, FEATHER, ME, FIRE, BABY, FRAUD, GOD, PATRIOT, TORNADO, WORD, MOTHER, STATUE, COP, AMERICA. Data za jednotlivé pojmy byla "vyskládána" pod sebe. Pro každou dvojici adjektiv bylo použito $20 \times 100=2000$ údajů. Na data byla aplikována faktorová analýza, konkrétně Thurstoneova centroidní metoda; byly extrahovány 4 faktory, které byly podrobeny rotaci. ${ }^{7}$ Vyšly následující výsledky z hlediska procent vysvětlitelnosti celkové variability s nejsilnějšími jednoznačnými vazbami na uvedené dvojice adjektiv u nejsilnějších třech faktorů:

- Faktor I-33,78\% (good-bad, beautiful-ugly, sweet-sour, clean-dirty, tastydistasteful, ...)

- Faktor II - 7,62\% (large-small, strong-weak, heavy-light, thick-thin, ...)

- Faktor III-6,24\% (fast-slow, active-passive, hot-could, sharp-dull, ...)

- Faktor IV - 1,52\%.

Čtyři faktory vysvětlily $49 \%$ celkové variability, první tři přibližně $48 \%$. První faktor byl označen jako hodnocení (evaluation), druhý jako potence (potency), třetí jako aktivita (activity). Po rotaci je faktor hodnocení více než 4krát "silnější" než další dva relativně vyvážené faktory; čtvrtý faktor má výrazně nižší sílu než předcházející dva, a proto mu nebyla věnována další pozornost. Přesto je potřeba poukázat také na fakt, že tři vybrané faktory vysvětlují necelých $50 \%$ celkové variability. Osgood; Suci; Tannenbaum $(1957$, s. 73) uvádějí možnost v určitých př́padech nahradit faktory II a III jedním označeným dynamism. Označení potence a aktivita patrně našlo

4 Z tohoto důvodu se nejčastěji volí podmínka rotace varimax, která natáčí faktory tak, aby se v matici faktorových zátěží korelační koeficienty posunuly bud' k 1, -1 nebo naopak k 0 a usnadnily interpretaci faktorů.

5 Jednoduššími interpretacemi myslíme tvrzení o existenci tří dimenzí, zpravidla chápaných jako rovnocenné - bez diskuse o procentu vysvětlitelnosti rozptylu.

6 Problém překladu dvojic adjektiv je zde zásadní. Jedná se o odlišnosti v jemných významových nuancích, které se promítají do vzájemných korelací a i do korelací mezi škálami, tedy do nalezených faktorů. Na odlišnosti matice faktorových zátěží pro anglická adjektiva a "pokusy“ o české ekvivalenty upozornil i Chráska (2007).

7 Ačkoliv Osgood neuvedl konkrétní metodu rotace, Ize předpokládat, že se jednalo o nejrozšírenějšís podmínkou varimax. 
inspiraci ve fyzice jako paralela k potenciální a kinetické energii (srov. např. Chráska 2007, s. 228).

\subsubsection{DOTAZNÍK ATER}

Dotazník ATER (Attitude Towards Educational Reality) byl vytvořen Chráskou (2003, 2007). Na základě realizovaných vlastních výzkumů (viz např. Chráska 1998), postupnými úpravami a provedením faktorových analýz byla navržena dvoudimenzionální podoba sémantického diferenciálu, která je výhodná pro posuzování pojmů (objektů) "pedagogické (edukační) reality" (nebot' "analýza tř́ faktorů je až príliš detailní" (srov. Chráska 2003, s, 57). ATER se skládá z celkem 10 škál, z nichž 5 škál měři faktor hodnocení a 5 energie; některé jsou uspořádány reverzně (se záměrem narušit př́padné nežádoucí stereotypy při posuzování). Vedle „nejsilnějšího" faktoru hodnocení je identifikován faktor energie (slučující osgoodovské faktory aktivity a potence) a využívá následující dvojice adjektiv:

dimenze hodnocení: dobrá-špatná, příjemná-nepřijemná, světlá-tmavá, krásná-ošklivá, sladká-kyselá

dimenze energie: náročná-nenáročná, přísná-mírná, obtí̌ná-snadná, problémová-bezproblémová, těžká-lehká.

S pomocí ATERu byly posuzovány pojmy: DOMÁCÍ PŘíPRAVA NA VYUČOVÁNÍ; NAŠE ŠKOLA; STUDIUM NA STŘEDNÍ ŠKOLE; UČENÍ; UČITEL, KTERÉHO JSEM MĚL NEJRADĚJI; UČITEL, KTERÉHO JSEM NEMĚL RÁD; VYSVĚDČENÍ; VZDĚLÁNÍ; ZKOUŠENÍ; ZNÁMKOVÁNÍ. Dotazník byl zadán 523 patnáctiletým žákům, kteř́ ve školním roce 1998-99 navštěvovali poslední ročník povinné školní docházky (205 žáků končilo povinnou školní docházku v 9. ročníku základní školy a 218 na víceletém gymnáziu). Data byla pro jednotlivé dvojice adjektiv uspořádána pod sebe za všechny žáky a všechny pojmy, pro faktorovou analýzu byl tak připraven soubor o 523 (žáků) x 10 (pojmů) = 5230 rádcích.

Pro extrahování faktorů byla použita metoda hlavních komponent a následně rotované řešení s podmínkou varimax. Dva faktory odpovídající odhadovaným dimenzím vysvětlily téměř $70 \%$ celkové variability. Vnitřní konzsistence obou dimenzí byla kolem 0,85 či vyšší.

\subsection{OBECNÉ MOŽNOSTI ZPRACOVÁNÍ DAT ZÍSKANÝCH SÉMANTICKÝM DIFERENCIÁLEM}

Sémantický diferenciál nabízí několik variant analýz dat. Základní možnosti klasifikuje Ferjenčík (2000):

1) analýza odpovědí na úrovni jednotlivých položek (adjektiv),

2) analýza odpovědí na základě hodnocení globální podobnosti,

3) analýza odpovědí na úrovni jednotlivých dimenzí.

Analýzám odpovídají i možnosti číselné, tabulkové či grafické prezentace dat. 
V prvém prípadě bývají vytvářeny „profily“ pojmů, ve druhém matice vzdáleností a při třetí možnosti se jedná o umístění pojmů v sémantickém prostoru nebo jeho dvojdimenzionálních řezech.

Analýza, resp. další možné analýzy (např. statistické testování) založené na analýzách prvního typu se nijak zvlášt neliší od analýz škálových položek v běžných dotaznících.

Analýza druhého typu již skýtá nový náhled specifický pro sémantický diferenciál, a sice vyjádření vzdálenosti pojmů založené na matematickém modelu vícedimenzionálního prostoru (dimenze jsou dány dvojicemi bipolárních adjektiv). Vzdálenost pojmů je spočítána jako euklidovská vzdálenost v tomto prostoru vyjádřená jedním kladným číslem. Čím jsou si pojmy bližší, tím je toto číslo menší. Stále ještě se však v tomto typu analýzy neřeší problém redukce počtu škál, pracuje se s celým (byt pro názornost nepředstavitelným) vícerozměrným prostorem.

Analýzy třetího typu již nesou specifickou stopu sémantického diferenciálu objevenou Osgoodem, a sice možnost redukce počtu dimenzí na nižší počet, než je počet dvojic adjektiv. Někteří autoři na základě vlastních faktorových analýz a na ně navazujících postupů volí jiný počet dimenzí, např. dvě jako v případě dotazníku ATER. Jednou z předností redukce je možnost výsledky graficky prezentovat, a učinit je tak názornějšími. $V$ prípadě dvou faktorů je prezentace nasnadě, $v$ případě tři či více dimenzí se musí volit vhodné dvojdimenzionální řezy. Specificky se však $v$ konkrétním př́padě musí rozhodnout ${ }^{8}$, jakým způsobem k redukci dojde.

\subsection{SHRNUTÍ}

Dá se říci, že existují dva přístupy k práci se sémantickým diferenciálem. V prvním prípadě se výzkumník spolehne na ověřené dimenze a $k$ nim příslušné škály: dvojice bipolárních adjektiv. Ve druhém pak výzkumník na základě dat ladí konkrétní podobu sémantického diferenciálu obměnou škál a specifikací oblasti pojmů (objektů), pro které jsou dané škály nejvíce relevantní.

Osgood neusiloval o redukci oblasti posuzovaných pojmů a někteř́ autoři ve svých výzkumech se spoléhají na jím navržené dimenze a jim přiřazené dvojice adjektiv (např. Pöschl 2005, Starý 2006, Šlímová 2009).

Druhý prístup uvedený v této studii, reprezentovaný Chráskou ${ }^{9}$, vychází z toho,

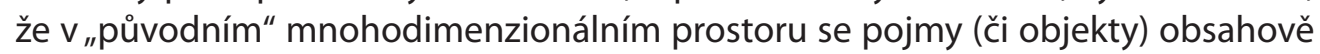
blízké nacházejí ve vlastním podprostoru, resp. jejich promítnutí do podprostoru nabídnutém Osgoodem je méně výhodné (ztratí se více informace o rozmístění pojmů). V první fázi provede výběr odpovídajícího podprostoru sám výzkumník tím, že volí relevantní dvojice adjektiv pro dané pojmy (objekty). Využitím faktorové analýzy pak dochází $k$ dalším obměnám škál - posilována je významová blízkost

8 Rozvaha je odpovídající rozvahám při vzniku běžně užívaných standardizovaných testů či dotazníků, které obsahují řadu položek za účelem vyšší obsahové validity a reliability (ve smyslu vnitřní konzistence) „nadřazené" dimenze.

9 Obdobně postupoval i např. Vala (2004). 
škál (až synonymičnost) koncentrovaná kolem identifikovaných faktorů (zvyšuje se tak vnitřní konzistence nalezených dimenzí odpovídajícího podprostoru). Výzkumník tedy sám definuje podprostor, který pokládá za relevantní k rozmístění pojmů daného obsahového okruhu.

Obecně se dá ríci, že pro každý pojem existuje určitý okruh relevantních adjektiv. Při snaze využít sémantický diferenciál se však musí stejná adjektiva použít pro více pojmů. Nemůže pak překvapit fakt, že pro širší okruh pojmů bude obtížnější nalézt adjektiva relevantní pro všechny pojmy. Např. Chráskou navržené škály vysvětlily na jiném vzorku ve dvoufaktorovém modelu od $48 \%$ do $60 \%$ celkové variability pro různé pojmy edukační reality. Taktéž je zřejmé, že metoda hlavních komponent vždy maximalizuje s daným počtem faktorů na daných datech procento rozptylu, které tyto faktory vysvětlují. Jestliže se na daných datech metodou hlavních komponent "vyladí" škály, je zákonité, že v jiném výzkumu, na jiných datech, musí klesnout procento rozptylu, které daný počet faktorů vysvětluje. Výzkumník se nachází opět v pokušení "ladit" škály na těchto nových datech. V tomto smyslu poskytují stabilnější výsledky jiné metody faktorové analýzy - např. metoda maximální věrohodnosti či Osgoodem použitá Thurstoneova centroidní metoda (McDonald 1991).

Vzhledem k prezentovaným výsledkům se ještě nabízí otázka, zda nepoužít jinou metodu faktorové analýzy, která nepočítá s kolmostí (nekorelovaností) faktorů. Nabízí se to zejména proto, že faktor hodnocení vychází opakovaně jako nejsilnější faktor a při ověřování korelace mezi dimenzemi vychází, že nejsou nezávislé. Chráska ověřil prostřednictvím konfirmatorní faktorové analýzy, že faktorový model $s$ nekolmými faktory by byl podstatně výhodnější. Nicméně, problémem takového modelu je jeho obtížná představitelnost a interpretovatelnost výsledků.

Lze shrnout, že pro porozumění výsledkům ze sémantického diferenciálu stačí pracovat s navrženými dimenzemi, prezentovat výsledky ve dvojdimenzionálních řezech a počítat s tím, že tyto dimenze nejsou nezávislé. Vazbu mezi dimenzemi Ize vyjádřit pomocí korelačního koeficientu. Použitelné dimenze lze nalézt "běžnými“ metodami faktorové analýzy s kolmými faktory. A odpověd’ na otázku výhodnosti některého z přístupů spočívá v rozhodnutí výzkumníka, zda chce zjistit vzájemné umístění (vzdálenost) pojmů, které jsou od sebe obsahově dosti vzdálené, či naopak má na mysli velmi úzký okruh pojmů (či objektů), které chce co nejlépe popsat i z hlediska jejich rozmístění v (pro ně) relevantních dimenzích.

\section{SÉMANTICKÝ DIFERENCIÁL A JEHO VYUŽITÍ V PRŮBĚHU AUTOEVALUACE}

Sémantický diferenciál může být ve školské praxi a v životě škol využitelný zejména pro zjištování postojů větší skupiny lidí, Vzhledem ke své charakteristice (tj. díky schopnosti měrit postoje, pro laiky zdánlivě lehké administraci, pro respondenty relativně nenáročnému vyplňování) se jeví jako vhodná metoda i pro zjištování informací potřebných v rámci autoevaluace školy. 
Pro ověření uvedeného předpokladu byly vybrány tři české základní školy s rozdílnými, ale i shodnými rysy. Jednalo se o základní školy (ZŠ) mající relativně jasnou svou vizi, o které je v posledních letech poměrně velký zájem ze strany žáků i rodičů. Každá z nich je vyprofilována specifickým způsobem (důraz na všeobecné a rovné vzdělávání pro všechny žáky; profilace na rozšířenou výuku jazyků či matematiky).

Jelikož realizace autoevaluace není univerzální a každá organizace si musí s využitím obecných zásad a prípadně zkušeností jiných najít svou cestu, byl při výběru škol kladen důraz na záměr postihnout co nejrůznější přístupy k autoevaluaci. Charakter přístupu k evaluačním procesům uvnitř školy v ZŠ1 vystihuje pasáž uvedená v poslední inspekční zprávě: „....získané informace byly analyticky zpracovány a účelně využity k zvyšování kvality vzdělávání..."; autoevaluace je řadu let pevnou součástí práce celé školy a přináší řadu cenných podnětů pro její další rozvoj. V ZŠ2 se jedná o př́istup, kdy se určitá skupina lidí snaží o smysluplnost práce včetně autoevaluačních procesů, zatím co zbytek školy přistupuje $k$ věcem formálně; škola prošla před nedávnem sloučením, takže existují dvě poměrně odlišná vnímání žádoucího způsobu fungování školy a z toho plynoucí nejednotnost učitelského sboru. V ZŠ3 Ize autoevaluaci (a i styl vedení) charakterizovat slovy jedné vyučující "autoevaluaci dělá pan ředitel - používáme dotazníky pro žáky, rodiče, učitele, s jejich výsledky se u nás moc nepracuje".

Ve vybraných školách byly sledovány možnosti a limity využití sémantického diferenciálu při autoevaluaci ale i to, zda výsledky získané touto metodou budou korespondovat s uvedenými charakteristikami škol.

Při konstrukci sémantického diferenciálu byly jako klíčové vybrány pojmy zapadající do oblasti „pedagogické reality“ (viz Chráska 2003). Byly doplněny ještě o další pojmy mající vztah k hodnocení výsledků vzdělávání. Byly navrženy řediteli, nebot' je zajímalo, jak je žáci vnímají; finální výběr byl proveden po konzultacích s odborníky na školský management. $\mathrm{K}$ posuzování byly tedy stanoveny pojmy: NAŠE ŠKOLA, VYUČOVÁNÍ, SPRAVEDLNOST UČITELŮ, ${ }^{10}$ PRAVIDLA ZNÁMKOVÁNÍ, SEBEHODNOCENÍ ŽÁKŮ.

\subsection{METODOLOGIE VÝZKUMU}

V rámci předvýzkumu (květen - červen 2009), který byl realizován na dvou ZŠ, byla na základě faktorové analýzy (metoda hlavních komponent a rotace varimax) u každé dimenze vynechána jedna dvojice adjektiv - v dimenzi energie "problémová-bezproblémová" a pro dodržení požadavku na stejný počet škál byla pro každou z dimenzí z dalšího zpracovávání vyloučena i nejslabší škála v dimenzi hodnocení, „světlá-tmavá". Důvodem vyloučení bylo zvýšení \% celkové variability a vyšší konzistence jednotlivých dimenzí (\% celkové variability narostlo přibližně o $4 \%$ na $54 \%$ na jedné, resp. na $62 \%$ na druhé ZŠ). Vnitřní konzistence obou dimenzí se pohybovala mezi 0,7 a 0,8 (podrobněji viz dále). Na základě vyladění relevance

10 Pojem SPRAVEDLNOST UČITELŮ byl žákům při zadávání vysvětlen tím způsobem, že mají posuzovat spravedlnost, se kterou se u učitelů setkávají ve své škole. 
dvojic adjektiv pro konkrétní pojmy byla modifikace ATERu použita pro účely níže prezentovaného výzkumu.

Vlastní výzkum probíhal v průběhu roku 2009 (od června do záŕí 2009) a dotazník ATER byl distribuován mezi žáky druhého stupně tři zmíněných základních škol. Zadáván byl bud'učiteli škol (po proškolení), nebo spoluautorkou textu. Po selekci nesprávně vyplněných dotazníků jich bylo analyzováno celkem 417. Získaná data byla pro jednotlivé dvojice adjektiv uspořádána pod sebe za všechny žáky a za všechny pojmy, pro faktorovou analýzu tak byl připraven soubor o 417 (žáků) $\times 5$ (pojmů) = 2085 rádcích. Získaná data byla podrobena faktorové analýze s využitím metody hlavních komponent a rotovaného řešení s podmínkou varimax (normalizované). Výsledky matice faktorových zátěží přináší tabulka č. 1. Celkově faktory vysvětlují $59 \%$ celkové variability, konkrétněji faktor energie $28 \%$; faktor hodnocení $31 \%$. Při nerotovaném řešení by sám nejsilnější faktor vysvětlil $44 \%$ celkové variability.

Tabulka č. 1 Matice faktorových zátěží

\begin{tabular}{|l|r|r|}
\hline \multicolumn{3}{|c|}{ faktor HODNOCENÍ } \\
\hline špatná-dobrá & 0,762 & $-0,166$ \\
\hline nenáročná-náročná & $-0,111$ & 0,696 \\
\hline nepř́íjemná-pŕíjemná & 0,778 & $-0,187$ \\
\hline mírná-přísná & $-0,270$ & 0,643 \\
\hline snadná-obtížná & $-0,178$ & 0,794 \\
\hline ošklivá-krásná & 0,791 & $-0,196$ \\
\hline kyselá-sladká & 0,703 & $-0,280$ \\
\hline lehká-těžká & $-0,249$ & 0,737 \\
\hline \% variability & $31 \%$ & $28 \%$ \\
\hline
\end{tabular}

Vnitřní konzsistence dimenzí hodnocení a energie byla zjištována pomocí Cronbachova alfa a jejich nezávislost pomocí korelačního koeficientu. Faktory při zvolené faktorové analýze byly konstruovány jako kolmé (nezávislé), ale pro jednotlivé dimenze vzniklé pomocí součtů či průměrů vybraných škál již nezávislé být nemusí, což napověděl i silný dominující jeden faktor při nerotovaném řešení faktorové analýzy. Byly získány následující výsledky:

Dimenze hodnocení - Cronbachovo alfa 0,795

Dimenze energie - Cronbachovo alfa 0,734

Korelační koeficient mezi dimenzemi je záporný -0,509.

Vzhledem ke zjištěné dominanci jednoho společného faktoru a silnému korelačnímu koeficientu mezi dimenzemi byla ověřena ještě vnitřní konzistence všech škál společně. Pro tento účel musely být škály energie otočeny z důvodu záporné korelace mezi dimenzemi; Cronbachovo alfa pak bylo 0,821. Otázkou zůstávalo, jak souvisí $s$ dimenzemi hodnocení a energie. Korelační koeficient $s$ dimenzí hodnocení vyšel o něco vyšší, 0,884; s dimenzí energie pak 0,853. Z jednotlivých škál mu nejsilnější interpretaci nabízí škála hodnocení „ošklivá-krásná“ s korelačním koeficientem 0,709. 


\subsection{ZJIŠTĚNÍ}

Ukázalo se, že pro zkoumané pojmy jsou dimenze hodnocení a energie relevantní, ale že tyto dimenze nejsou nezávislé. Obecně se dá ríci, že když je něco (zde žáky) vnímáno jako náročné, obtížné, je to současně vnímáno jako horší, méně příjemné, ošklivější. Zajímavé pak mohou být právě individuální odchylky žáků, tříd, škol, které se tomuto vztahu vymykají.

Výsledky zkoumaných tř́ škol jsou prezentovány grafickým porovnáním profilů $v$ jednotlivých škálách u vybraných pojmů (první způsob prezentace z kap. 1. 2, zde grafy č. 1 a 2), dále je představeno rozmístění pojmů všech škol v sémantickém prostoru "hodnocení x energie" (graf č. 3) a porovnáním středních hodnot těchto dimenzí u jednotlivých pojmů t-testem (třetí způsob prezentace z kap.1.2, zde tabulky č. 2 a 3). Nakonec jsou uvedeny i matice vzdáleností mezi pojmy na každé škole zvlášt' (druhý způsob prezentace z kap.1.2, zde tabulky č. 4, 5 a 6).

Graf č. 1: Profil pojmu PRAVIDLA ZNÁMKOVÁNÍ

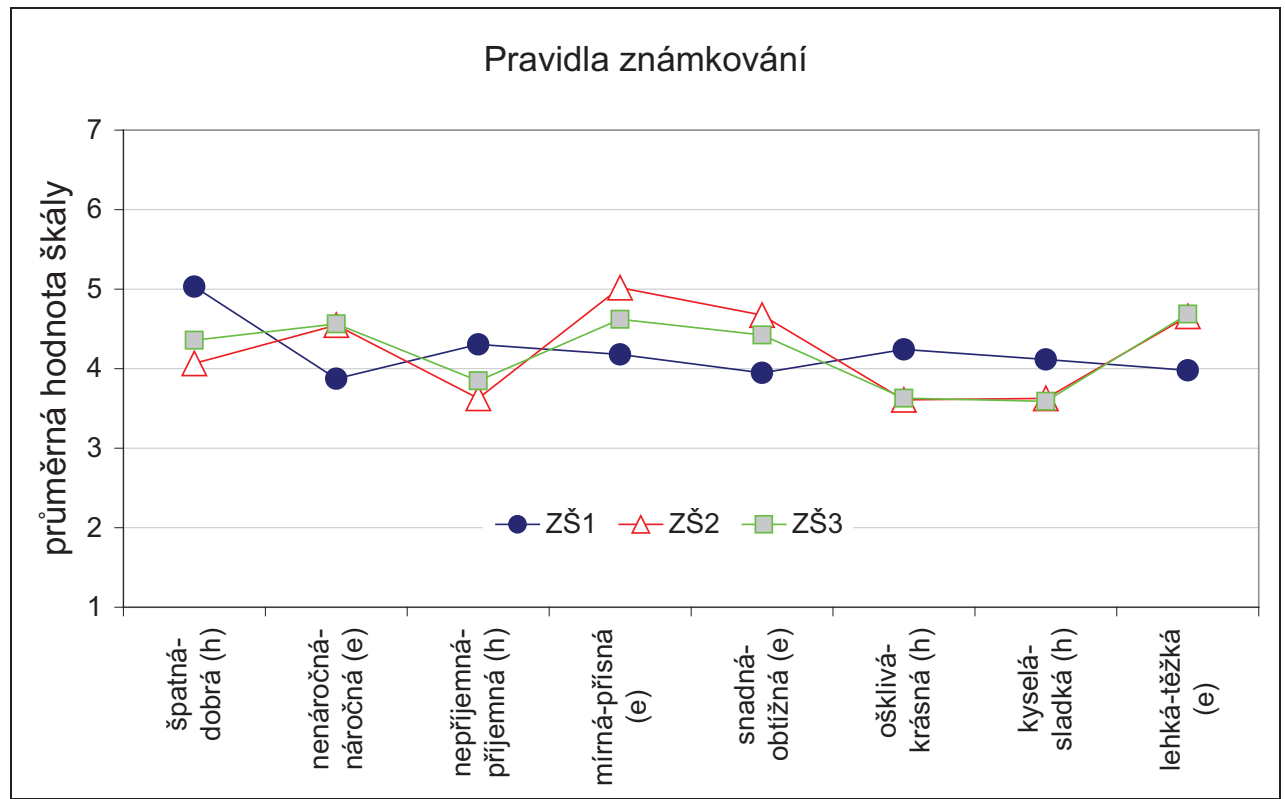


Graf č. 2 : Profil pojmu SPRAVEDLNOST UČITELŮ

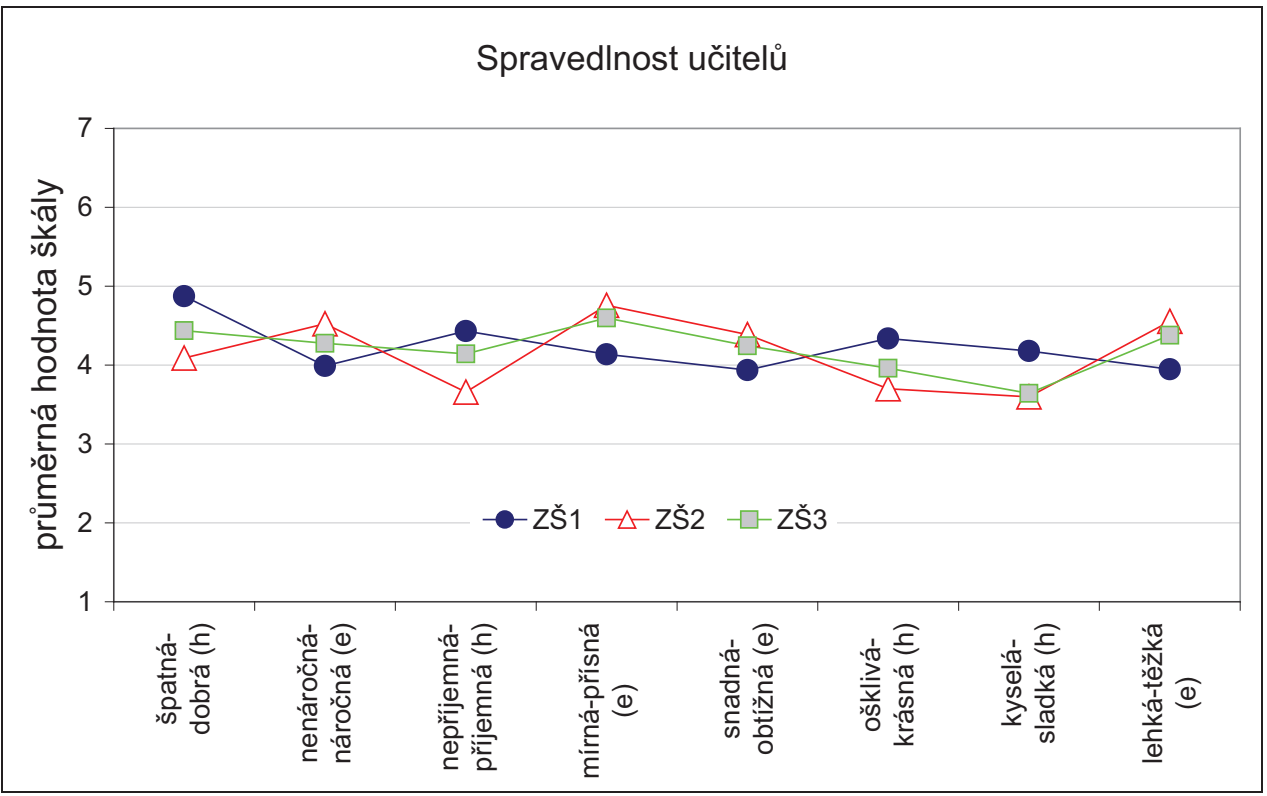

Tabulka č. 2 Porovnání výsledků tří škol v dimenzi energie

\begin{tabular}{|c|c|c|c|c|c|c|c|c|c|}
\hline \multirow{2}{*}{$\begin{array}{l}\text { Dimenze } \\
\text { ENERGIE }\end{array}$} & \multicolumn{2}{|c|}{ ZŠ1 } & \multicolumn{2}{|c|}{ ZŠ2 } & \multicolumn{2}{|c|}{ ZŠ3 } & \multirow{2}{*}{ 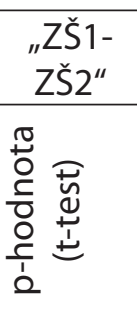 } & \multirow{2}{*}{ 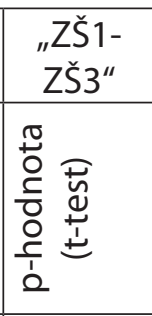 } & \multirow{2}{*}{ 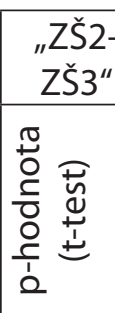 } \\
\hline & 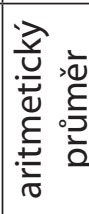 & 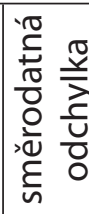 & 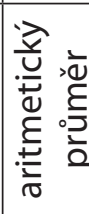 & 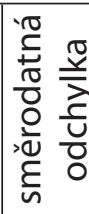 & 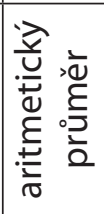 & 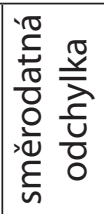 & & & \\
\hline Naše škola & 3,82 & 0,76 & 4,55 & 1,09 & 4,45 & 0,93 & $p<0,001$ & $p<0,001$ & 0,3526 \\
\hline Vyučování & 3,88 & 0,84 & 4,55 & 1,06 & 4,46 & 0,95 & $p<0,001$ & $p<0,001$ & 0,4203 \\
\hline $\begin{array}{l}\text { Sprave- } \\
\text { dlnost } \\
\text { učitelů }\end{array}$ & 4,00 & 0,78 & 4,56 & 1,06 & 4,37 & 1,03 & $p<0,001$ & $p<0,01$ & 0,1204 \\
\hline $\begin{array}{l}\text { Pravidla } \\
\text { známko- } \\
\text { vání }\end{array}$ & 3,99 & 0,77 & 4,72 & 1,15 & 4,57 & 1,10 & $p<0,001$ & $p<0,001$ & 0,2319 \\
\hline $\begin{array}{l}\text { Sebehod- } \\
\text { nocení } \\
\text { žáků }\end{array}$ & 3,81 & 1,06 & 3,71 & 1,29 & 3,54 & 1,25 & 0,5216 & 0,0831 & 0,2375 \\
\hline
\end{tabular}


Tabulka č. 3 Porovnání výsledků tří škol v dimenzi hodnocení

\begin{tabular}{|c|c|c|c|c|c|c|c|c|c|}
\hline \multirow[t]{2}{*}{$\begin{array}{c}\text { Dimenze } \\
\text { HODNOCENÍ }\end{array}$} & \multicolumn{2}{|c|}{ ZŠ1 } & \multicolumn{2}{|c|}{ ZŠ2 } & \multicolumn{2}{|c|}{ ZŠ3 } & \multirow{2}{*}{ 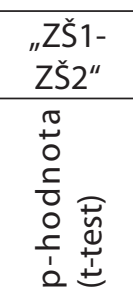 } & \multirow{2}{*}{ 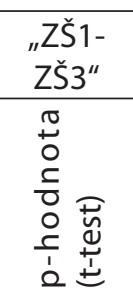 } & \multirow{2}{*}{ 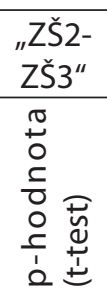 } \\
\hline & 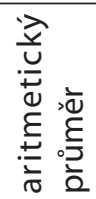 & 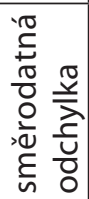 & 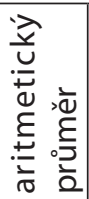 & 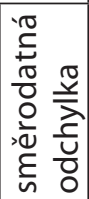 & 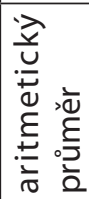 & 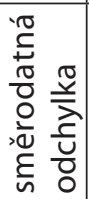 & & & \\
\hline Naše škola & 5,30 & 0,85 & 4,45 & 1,22 & 4,74 & 1,10 & $p<0,001$ & $p<0,001$ & $p<0,05$ \\
\hline Vyučování & 4,78 & 0,95 & 4,14 & 1,22 & 4,29 & 1,07 & $p<0,001$ & $p<0,001$ & 0,2386 \\
\hline Spravedlnost učitelů & 4,46 & 1,01 & 3,76 & 1,31 & 4,04 & 1,18 & $p<0,001$ & $p<0,01$ & $p<0,05$ \\
\hline Pravidla známkování & 4,42 & 0,89 & 3,73 & 1,32 & 3,86 & 1,12 & $p<0,001$ & $p<0,001$ & 0,3677 \\
\hline Sebehodnocení žáků & 4,61 & 1,16 & 4,55 & 1,36 & 4,66 & 1,31 & 0,7180 & 0,7668 & 0,4662 \\
\hline
\end{tabular}

Graf č. 3: Prezentace pojmů v sémantickém prostoru

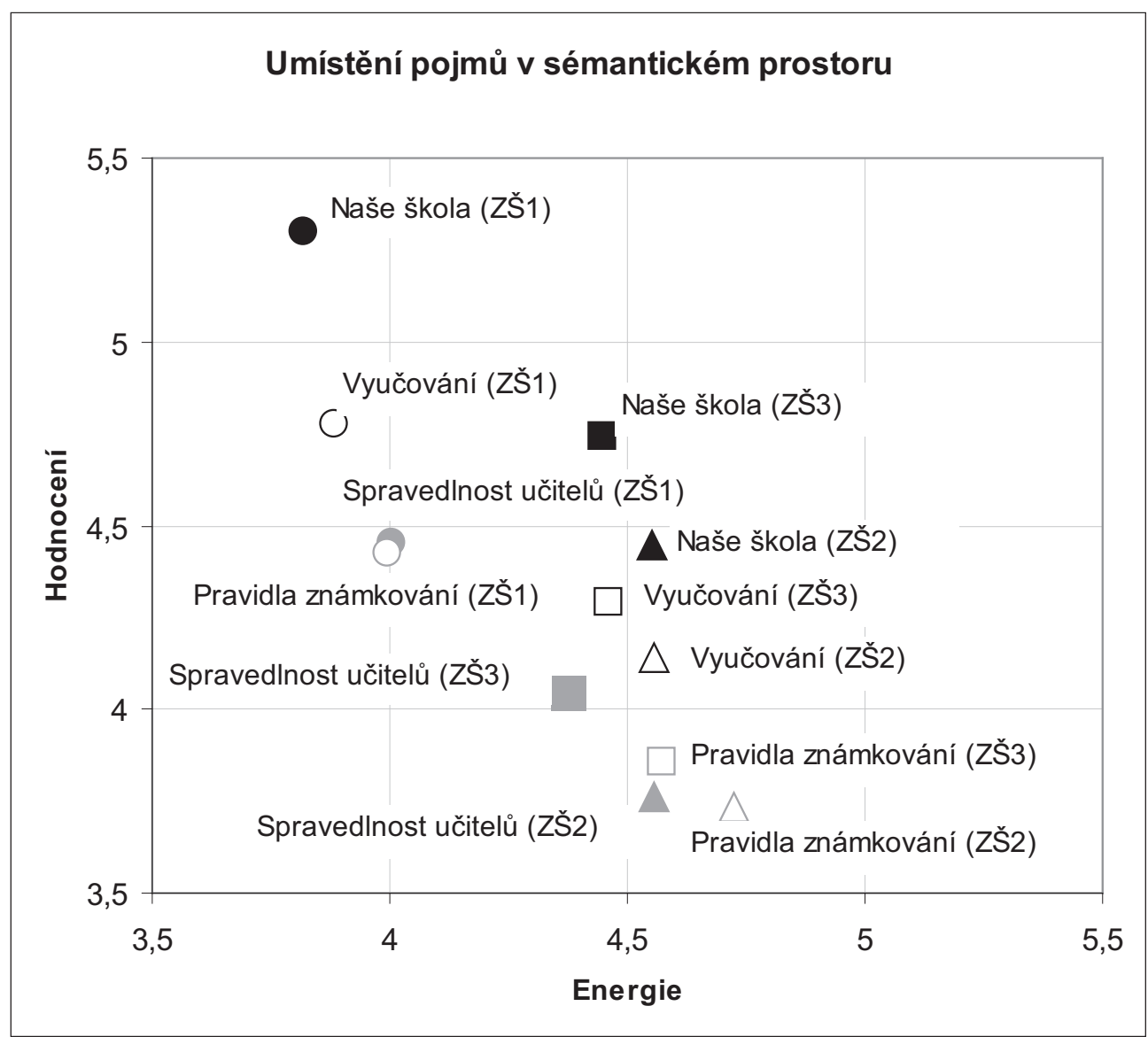

Poznámka ke grafu: Každá škola má v grafu u jednotlivých pojmů stejný tvar značky - ZŠ1 kolečko, ZŠ2 trojúhelníček, ZŠ3 čtvereček. Stejné pojmy mají shodnou „barevnost". 
Z tabulek 2 a 3 je patrné, že ZŠ1 se statisticky významně ( $5 \%$ hl. význ., někdy i 1\% hl. význ.) liší od ZŠ2 a ZŠ3 z hlediska vnímání pojmů NAŠE ŠKOLA, VYUČOVÁNÍ, SPRAVEDLNOST UČITELŮ, PRAVIDLA ZNÁMKOVÁNÍ. Liší se v obou sledovaných dimenzích - hodnocení i energie. ZŠ1 má u jmenovaných pojmů vyšší hodnoty v dimenzi hodnocení a nižší hodnoty v dimenzi energie (taktéž viz graf č. 3).

Všechny tři školy jsou srovnatelné v postojích žáků vůči pojmu Sebehodnocení žáků.

Z grafu č. 3 je patrná zjištěná závislost obou dimenzí - s vyšším hodnocením nějakého pojmu $v$ dimenzi hodnocení, klesá jeho hodnocení v dimenzi energie. Patrné jsou i určité trendy. Jednotlivé pojmy jsou vưči sobě posunuté - např. při shodné vnímané energetické náročnosti pojmů z jedné školy je nejvýše hodnocen pojem NAŠE ŠKOLA, níže VYUČOVÁNÍ, nejníže a sobě relativně nejblíže pojmy SPRAVEDLNOST UČITELŮ a PRAVIDLA ZNÁMKOVÁNÍ. U všech pojmů v daném trendu je shodné pořadí - ZŠ1, se statisticky významným odstupem ZŠ3 a dále většinou již bez statisticky významného rozdílu ZŠ2 (tabulky č. 2 a 3). Vhled to těchto vztahů přináśí i matice vzdáleností mezi pojmy na jednotlivých školách (tabulky č. 4, 5 a 6).

Dalo by se říci, že žáci na jednotlivých školách z hlediska energie (náročnosti, obtížnosti) vnímají školu shodně s vyučováním, spravedlností učitelů i pravidly známkování, ale nejpozitivnější vztah z hlediska dimenze hodnocení mají ke škole, pak k vyučování a nejméně „rádi“ mají spravedlnost učitelů vnímanou právě ve spojení s pravidly známkování.

Tabulka č. 4: Matice vzdáleností pojmů na ZŠ111

\begin{tabular}{|c|c|c|c|c|c|}
\hline 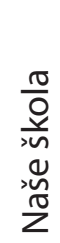 & 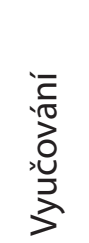 & 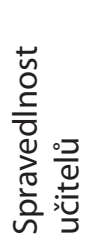 & 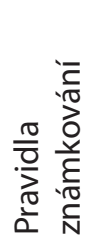 & 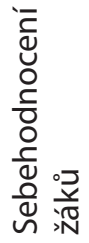 & \\
\hline & 1,35 & 1,90 & 1,97 & 1,75 & Naše škola \\
\hline & & 0,85 & 0,85 & 0,78 & Vyučování \\
\hline & & & 0,25 & 0,65 & Spravedlnost učitelů \\
\hline & & & & 0,77 & Pravidla známkování \\
\hline & & & & & Sebehodnocení žáků \\
\hline
\end{tabular}

11 Tmavší pozadí polí naznačuje větší vzdálenost pojmů. 
Tabulka č. 5: Matice vzdáleností pojmů na ZŠ2

\begin{tabular}{|c|c|c|c|c|c|}
\hline 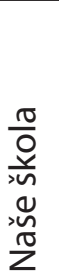 & مَ & 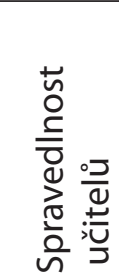 & 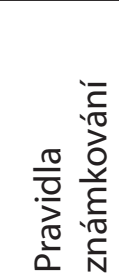 & 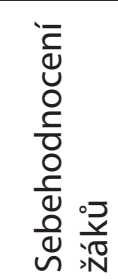 & \\
\hline & 0,70 & 1,46 & 1,56 & 1,57 & Naše škola \\
\hline & & 0,89 & 1,06 & 1,63 & Vyučování \\
\hline & & & 0,42 & 2,01 & Spravedlnost učitelů \\
\hline & & & & 2,35 & Pravidla známkování \\
\hline & & & & & Sebehodnocení žáků \\
\hline
\end{tabular}

Tabulka č. 6: Matice vzdáleností pojmů na ZŠ3

\begin{tabular}{|c|c|c|c|c|c|}
\hline $\begin{array}{l}\frac{\pi}{0} \\
\frac{0}{n} \\
0 \\
\infty \\
\frac{n}{z}\end{array}$ & 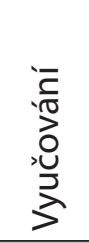 & 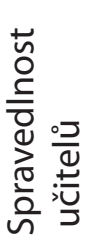 & 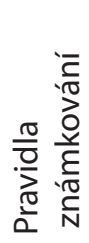 & 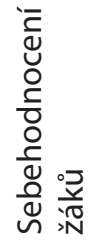 & \\
\hline & 0,83 & 1,49 & 1,77 & 1,82 & Naše škola \\
\hline & & 0,78 & 0,97 & 1,81 & Vyučování \\
\hline & & & 0,63 & 1,87 & Spravedlnost učitelů \\
\hline & & & & 2,38 & Pravidla známkování \\
\hline & & & & & Sebehodnocení žáků \\
\hline
\end{tabular}

Z matice vzdáleností mezi pojmy je vidět, že žáci ZŠ1 mají svoji školu oproti žákům ZŠ2 a ZŠ3 méně spojenou pouze s vyučováním. Žáci ZŠ1 pak mají vyučování spojeno vyváženě jak se spravedlností učitelů, s pravidly známkování, tak i se sebehodnocením žáků, zatímco žáci ZŠ2 a ZŠ3 vyučování se sebehodnocením př́liš spojeno nemají. Obdobně žáci ZŠ1 mají sebehodnocení žáků spojeno se spravedlností učitelů a pravidly známkování, naopak žáci ZŠ2 a ZŠ3 sebehodnocení žáků s pravidly známkování spojeno nemají (absolutně největší vzdálenosti mezi použitými pojmy). Společně na všech školách mají žáci spojenu spravedlnost učitelů s pravidly známkování, na ZŠ1 je tato vazba nejtěsnější, na ZŠ3 je nejméně těsná.

Žáci ZŠ1 vnímají uvedené pojmy jako lepší, príijemnější než žáci zbývajících dvou škol, ale zároveň jako méně náročné. Dá se tedy říci, že v této škole dochází k rozvoji pozitivních postojů žáků vůči škole, vyučování i vůči zpětné vazbě od učitelů promítající se do pravidel známkování a spravedlnosti jejich př́ístupu k žákům. Ve škole je patrně pěstována kultura ve smyslu "chybovat se smí, i chybování je cestou k cíli". Poznatky z dalších dvou škol jsou ze statistického hlediska téměř shodné - dá se 
říci, že žáci z těchto škol zaujímají méně pozitivní postoj vůči škole jako takové, vyučování, pravidlům známkování a i vůči spravedlnosti učitelů než v ZŠ1. Interpretace těchto zjištění (jako nutné součásti autoevaluačních procesů) je již především na individuální škole.

Při sledování využitelnosti dotazníku na bázi sémantického diferenciálu v autoevaluační praxi škol je nutno na odpověd' nahlédnout ze dvou hledisek. Při posuzování využitelnosti dotazníku na bázi sémantického diferenciálu pro autoevaluační praxi škol je třeba vyjít ze dvou hledisek: hledisko "technicko-matematické" sleduje náročnosti administrace a vyhodnocení a hledisko "obsahové výpovědi" se vztahuje k významu pro školu samotnou „Výzkumníci laici“" (tj. pedagogičtí pracovníci) se při realizaci setkávali s řadou úskalí - počínaje samotným zadáváním dotazníku respondentům (nutnost naklonit je myšlence smysluplnému vyplňování), přes přepis dat do digitální podoby až po následné vyhodnocení. V prezentovaném šetření se patrně jako nejproblematičtější ukázala být motivace respondentů, kdy např. u žáků šestého či sedmého ročníku bylo obtížné vysvětlit jim způsob práce se škálami (zapojení spoluautorky textu do zadávání se ukázalo užitečné). Roli hrál věk respondentů a jejich schopnost porozumět abstraktnějším pojmům, což se prokázalo např. u pojmu spravedlnost učitelů, jehož srozumitelnost narůstala $s$ věkem žáků. Úskalím se rovněž ukázala být interpretace výsledků, které při prezentaci za jednotlivé školy samostatně učitelům nepřinášely prakticky žádné nosné závěry - až přirovnáním $k$ výsledkům jiné školy bylo možno vyvodit $z$ šetření relevantnější a podnětné závěry (při dodržování anonymity původu šetření, což bylo velmi oceňováno). Prezentace poznatků grafickým způsobem ve dvojdimenzionálním prostoru byla shledána ve všech třech školách jako srozumitelný a využitelný způsob vhodný i pro následné sdílení s dalšími aktéry školního života. Je zjevné, že $z_{\text {I }}$ technicko-matematického" hlediska mohou nároky na užití, se kterými se učitelé při běžném pracovním vytížení mohou stěží vyrovnat bez externí pomoci a podpory, převážit pozitivní potenciál sémantického diferenciálu pro autoevaluaci školy. Řešením by např. mohla být administrace dotazníku s využitím webového rozhraní, ze kterého by bylo možno data exportovat do Excelu, a které by umožnilo bezpečné srovnání škol; otázkou by však zůstával sponzor onoho rozhraní apod.

Druhé hledisko („obsahové výpovědi“) směřuje ke skutečnosti, že v běžné praxi škol může být aplikace sémantického diferenciálu velmi komplikovaná z důvodu neexistence referenčního rámce pro interpretaci výsledků. Možnost vytvořit hodnotící soud k informacím popisujícím aktuální stav v oblasti postojů žáků je možné učinit teprve na základě určitého srovnání, a to bud's jinými školami, jak zde bylo prezentováno, nebo $v$ rámci jedné školy mezi třídami nebo při opakovaných šetřeních porovnáním časových trendů či proměn na úrovni skupin během jejich průchodu školou. 


\section{DISKUSE}

Sémantický diferenciál může díky variabilitě možností zpracování přinášet celou řadu náhledů na postoje žáků k vybraným aspektům je obklopující školní reality. Jaká oblast reality žákủ školu zajímá, se pak musí do konkrétní podoby sémantického diferenciálu promítnout v podobě zvolených pojmů, pro které je třeba stanovit relevantní posuzovací škály. Jít cestou konstrukce je však časově i odborně přiliš náročné, byt' by se jí škola mohla vydat. Pro reálné využití lze spíše doporučit ověřené baterie škál i spolu s ověřenými pojmy. Př́kladem takového již připraveného nástroje je např. ATER či jeho v textu př́spěvku představená modifikace.

Vlastní zpracování výsledků v profilech pojmů přinese škole srozumitelný náhled interpretovatelný prímo v použitých škálách. Již na této úrovni mohou učitelé získat citlivost pro určité indikátory - výsledky na škálách, které mohou být porovnány se sprátelenými školami či v rámci školy mezi třídami, případně v časových řadách. Náročnější cesta zpracování pak je ve vyjádření výsledků v agregovaných dimenzích slučujících určité škály.

Dotazník ATER nabízí dimenze hodnocení a energie. Nicméně z výsledků i jiných výzkumů užití sémantického diferenciálu se ukazuje, že dimenze hodnocení má univerzální charakter a je použitelná na širokou paletu možných pojmů; je to také ta dimenze, která bude školy patrně nejvíce zajímat. To, co nabízí graf sémantického prostoru vizuálním náhledem, nabízí kvantitativně i matice vzdáleností mezi pojmy. Z té je možné vyčíst určité indikátory toho, co si žáci spojují se školou, s vyučováním nebo některými vybranými předměty. Někdy se mezi pojmy zjištované sémantickým diferenciálem zařazuji i takové, vưči kterým má význam sledovat právě vzdálenost ostatních pojmů. Takovými pojmy jsou např́ílad JÁ, BUDOUCNOST, LÁSKA. Stávají se určitými referenčními body v sémantickém prostoru a vypočítaná vzdálenost je opět určitým indikátorem, jehož interpretační význam nabude teprve v porovnání škol, tříd či během času.

Výsledky sémantického diferenciálu je možné zpracovávat i na úrovni jednotlivých žákủ. Je však potřeba upozornit, že se výsledky v žádném případě nesmí stát předmětem hodnocení žáků, tříd. Zjištění také nesmí vést $k$ hodnocení jednotlivých učitelů. Nicméně pro školu jsou výsledky interpretovatelné, a to v kontextu jejích celkových snah $v$ působení na postoje žáků. Je na škole samotné, aby uvážila, jakým žákům, v jaké podobě, kdy a v jaké periodicitě sémantický diferenciál zadat, u koho šetření opakovat a především, jak se získanými poznatky dále citlivě zacházet.

\section{ZÁVĚR}

Záměrem textu bylo přibližit možnosti využití sémantického diferenciálu v prostředí školy. Ukázalo se, že dotazník ATER se jeví jako upotřebitelný nástroj pro autoevaluaci školy, avšak jen tehdy, má-li škola možnost $v$ bezpečném prostředí porovnat své výsledky s jinými: např. srovnat své výsledky v průběhu času (např. 
každoročně), s partnerskými školami či se zjištěnými normami na anonymním vzorku škol. Pokud jsou tyto informace $k$ dispozici, může sémantický diferenciál poukázat na cosi důležitého, co by jinak mohlo zůstat skryto. Při mapování efektů snah školy pozitivně působit na postoje žáků by mohla nejvíce odpovídat autoevaluačním potřebám trendová porovnání, včetně případné komparace s jinými anonymizovanými školami.

Data prezentovaná v textu byla zpracována a poskytnuta zaangažovaným školám $(Z S ̌ 1,2,3)$, které s nimi budou dále pracovat. Reflexe využití výsledků školami samotnými bude možná až s určitým časovým odstupem. Již nyní se ale dá ríci, že výsledky pro ně byly cenným podnětem, nebot možnosti ke zjištění informací o postojích žáků, jako o důležitém aspektu výchovně-vzdělávacího procesu, byly pro školy dosud prakticky nulové. Z externího pohledu výsledky odpovídají některým charakteristikám škol - mohou tedy i poskytovat indikátory $v$ určitých oblastech kvality školy - o postojích žáků, v případě modifikovaného dotazníku ATER, ke škole samotné, k vyučování a hodnocení žáků.

Příspěvek byl sepsán za finanční podpory grantového projektu GA ČR 406/07/ P019 Možnosti využití autoevaluace a benchmarkingu ve škole.

\section{LITERATURA}

Bedrnová, E.; Nový, I. aj. Psychologie a sociologie rízení. Praha : Management Press, 1998. ISBN 80-85943-57-3.

Blahuš, P. Faktorová analýza a její zobecnění. Praha : SNTL, 1985.

Cohen, L.; Manion, L.; Morrison, K. Research Methods in Education. London : RoutledgeFalmer, 2007. ISBN 0-415-37410-3.

Ferjenčík, J. Úvod do metodologie psychologického výzkumu. Praha : Portál, 2000. ISBN 80-7178-367-6.

Hendl, J. Přehled statistických metod zpracování dat. Praha : Portál, 2004. ISBN 807178-820-1.

Chráska, M. Jaké jsou postoje žáků a studentů ke škole a edukační realitě? Pedagogika, roč. 48, 1998, č. 1, s. 54 - 66. ISSN 0031-3815.

Chráska, M. Metody sběru dat v evaluačních pedagogických výzkumech. Olomouc : Votobia Praha, 2003. ISBN 80-7220-164-6.

Chráska, M. Metody pedagogického výzkumu. Praha : Grada, 2007. ISBN 978-80-2471369-4.

Maršálová, L.; Mikšík, O. a kol. Metodológia a metody psychologického výskumu. Bratislava : SPN, 1990. ISBN 80-08-00019-8.

McDonald, R. P. Faktorová analýza a príbuzné metody v psychologii. Praha : Academia, 1991. ISBN 80-200-0081-X.

Miovský, M. Kvalitativní prístup a metody v psychologickém výzkumu. Praha : Grada, 2006. ISBN 80-247-1362-4.

Nakonečný, M. Encyklopedie obecné psychologie. Praha : Academia, 1997. ISBN 
8020006257

Osgood, Ch, E.; Suci, G., J.; Tannenbaum, P, H. The measurement of meaning. Urbana : University of Illinois Press, 1957. ISBN 0-252-74539-6.

Pelikán, J. Základy empirického výzkumu pedagogických jevů. Dotisk 1. vydání. Praha : Karolinum, 2004. ISBN 80-7184-569-8.

Pöschl, R. Vnímání významu matematiky a fyziky středoškolskými studenty. Diplomová práce. Praha : 2005. Vedoucí práce PhDr. Martin Chvál, Ph.D.

RVP ZV. Rámcový vzdělávací program pro základní vzdělávání, 2007 [online] [cit. 2007-08-22]. Dostupné na WWW: <http://www.rvp.cz/sekce/58>.

Starý, K. Efektivní výukové strategie. Disertační práce. Praha : 2006. Vedoucí práce doc. PhDr. Eliška Walterová, CSc.

Šlímová, J. Postoje ke studiu a jejich determinanty v procesu výchovy a vzdělávání.. In Učitelské povolanie v podmienkách súčasnej společnosti. Trnava : Katedra pedagogiky Filozofickej fakulty Univerzity sv. Cyrila a Metoda v Trnave a Slovenská pedagogická společnost' při SAV, 2009, s. 269-289. ISBN 978-80-8105-106-7.

Vala, J. Výzkum čtenářské recepce lyrické poezie metodou sémantického diferenciálu. Disertační práce. Olomouc : 2004. Vedoucí práce doc. PhDr. Vlasta Řeřichová, CSc.

Vala, J.; Vaštatková, J. Možnosti a limity využití sémantického diferenciálu při reflexi edukační reality. In Český pedagogický výzkum v mezinárodním kontextu. Sborník příspěvků XVII. ročníku celostátní konference ČAPV [CD-ROM]. Ostrava : PdF OU, 2010, s. 53-62. ISBN 978-80-7368-769-4.

Vaštatková, J. Úvod do autoevaluace školy. Dotisk 1. vydání. Olomouc : Univerzita Palackého, 2007. ISBN 80-244-1422-8.

Zákon č. 561/2004 Sb., o předškolním, základním, středním, vyšším odborném a jiném vzdělávání (školský zákon) [online] [cit. 2008-01-03]. Dostupné na WWW: <http:// www.msmt.cz/dokumenty/novy-skolsky-zakon>. 